\title{
The Impact of Project Performance on Customer Satisfaction
}

\author{
Ahmad Syamil $^{a}$, Jerry M. Samosir ${ }^{b}$, Pantri Heriyatic \\ ${ }^{a}$ Management Department, Binus Business School, International Undergraduate Program, Bina Nusantara University \\ ${ }^{b}$ Management Department, Binus Business School, Master Program, Bina Nusantara University \\ ${ }^{c}$ Management Department, Binus Business School, Doctor of Research in Management, Bina Nusantara University \\ aasyamil@binus.edu, ${ }^{\mathrm{c}}$ pheriyati@binus.edu
}

Article History: Received: 10 November 2020; Revised 12 January 2021 Accepted: 27 January 2021; Published online: 5 April 2021

\begin{abstract}
Introduction
Project management performance, which means the overall capability of the performing project team to deliver the project to satisfy the customer's requirements, has always been considered as one major key in achieving customer satisfaction, especially in a business-to-business organizational relationship. In this research, the researchers tried to find out how project performance actually impacts upon customer satisfaction. The project performance consisted of variables project scope management performance, project schedule management performance, project cost management performance, project human resource management performance, project risk management performance, project quality management performance, project communication management performance and project stakeholders management performance.

Method.

This research used quantitative approach. Data is collected through questionnaire distribution to companies in Jakarta and Bandung. Samples are respondent's representative of companies, hold managerial position or decision maker. From around 400 distrubuted questionnaire, this researched managed to collect 112 valid response from 112 companies. Data is analyzed its validity and reliability and hypotheses testing employ regression analysis with SPSS software.

Findings

The research found that, In Indonesia, especially for the private sectors (93\% of the respondents came from the private sectors, and only $7 \%$ come from public sectors), only four variables, which were project schedule, cost, human resources and risk management performance that significantly affected customer satisfaction. When the researcher interviewed 20 of the respondents most of them were the upper management in their organization, and most of them agreed on these findings.

One of the most acknowledged reason for this is because most of the projects in the respondents' projects were triggered by senior management decisions rather than fulfilling the organizations' needs or the project deliverables' users. These users were the ones who actually would use the project deliverables either in the form of products, applications, SOPs or even services. It was a very interesting finding, that many organizations actually conducted projects without actually needing the project's outcomes. An organization should create a project to support its program, portfolio, vision and mission.
\end{abstract}

Keywords: Scope management; project schedule management; project risk management; project quality management; project communication management; project stakeholders management performance

\section{Background}

A project is a temporary endeavor undertaken to create a unique product, service or result. In a business to business relationship project, the capability of the project team in delivering the project outcomes to match the needs and requirements of the user of the project is believed to impact the satisfaction of the customer, which in this case is the user of the project deliverables.

Inmanagingaproject,theprojectteamneedstoovercomemanychallengesthat may cause the project to not achieve the intended outcomes of the project. These challenges are usually called project constraints that will impact customer satisfaction. There are six constraints that can be measured as the project performance achievement whichare:

$\begin{array}{ll}- & \text { Scope } \\ - & \text { Quality } \\ - & \text { Schedule } \\ - & \text { Budget } \\ - & \text { Resources,and }\end{array}$


- $\quad$ Risks

Thecapabilityoftheperformingprojectteaminmanagingtheseconstraintsisassumed to be aligned with customer satisfaction and will be measured on this research. With a capable project team to manage the project's scope, quality, schedule, budget, resourcesandrisks,thehigherthechances areofcustomersbeingsatisfied.Managingscope means making sure that the required activities, services, tools, or products to deliver the project objectives/goals required to meet the customer requirements. Quality is all about meeting customer requirements. Schedule means meeting the customer's expectationonhowlong before theprojectshouldbefinished.Resourcesincludethehuman resources, tools and budget required to deliver the project objectives and meet customer expectations. Risk means that all possible threat for the project can be reduced as small aspossible, andalltheopportunitiescanbemaximizedforthebenefitsoftheproject.

\section{Research Question}

Based on the notion, the research question are as following:

1. Does the capability of the project team in managing the scopes, schedule, budget, human resources, risks, deliverables' quality, project communications, and project stakeholders make a positive impact on customersatisfaction?

2. Whatarethemostdominantfactorsoftheperformancethatsignificantlyimpact on customersatisfaction?

3. What are the business implications that can be concluded from the impact of project performance on customersatisfaction?

\section{Literature Review}

\section{Project Performance}

The ProjectManagementInstituteinthebook

'ProjectManagementBodyofKnowledge' (2013a),defined10areasthat aprojectteamshouldmanageindeliveringtheproject,and theyare:

1. Project IntegrationManagement

2. Project ScopeManagement

3. Project ScheduleManagement

4. Project CostManagement

5. Project Human ResourcesManagement

6. Project RiskManagement

7. Project QualityManagement

8. Project CommunicationManagement

9. Project ProcurementManagement

10.Project StakeholderManagement

The Project Management Institute and Microsoft (2005) published an essay on how effective project management benchmarking can be achieved, and there are several metrics that can be used, which are:

1. Project Cost ManagementPerformance

2. Project SchedulePerformance

3. Return onInvestment

4. Project Staffing and productivity

5. Project CycleTime

6. RiskManagement

7. Alignment to Strategic Business Goals (Scope and Communication Management) 


\section{CustomerSatisfaction}

ResearchbyBlanas G., Koukoumialos S. \& Kylindri S (2012)foundthatthemainfactorsthatcanbemeasuredforthe success of a project are time management, cost spending performance, quality of the project outcomes, resources management and performance in fulfilling the needs and desires of the customer that will lead to customer satisfaction. PM Solutions (2005) in their research found that the best practice to benchmark a project performance is by measuring the project requirements, quality, strategy alignment, budget, schedule, employee satisfaction, customer satisfaction, team productivity, risk management, time to market and changemanagement.

Based on this literature, the researcher decided to take scope, schedule, cost, human resource, risk, quality, communication and stakeholder management as the independent variables, that can impact customer satisfaction as the dependent variable. The researcher excluded integration management because it is thecombinationofallotherareas, andadedicatedprocurementteaminanorganization usually conducts procurement for the project. The capability of the project team in managing each variable is called project management performance, and we will measure the project performance for each variable in thisproject.

\section{Customer Satisfaction}

Akewushola et al. (2012), found that technical success in delivering the project contributed significantly to customer satisfaction because naturally technical success of the project will ensure that the scope of project execution is relevant to the needsandrequirementsofthecustomer. Thistechnicalsuccess is usuallymeasuredbased on the project performance itself, and according to Project Management Institute and Microsoft Dynamics (2005), there are several metrics in benchmarking the project management, whichare:

1. Project Cost Performance

2. Project Scheduleperformance

3. Return onInvestment

4. Project Staffingperformance

5. Project Teamproductivity

6. Project CycleTime

$7 . \quad$ Post-projectReview

8. Project RiskManagement

9. Project ScopeManagement

10. CustomerSatisfaction

The performance significantly impacts both directly and indirectly on customer satisfaction as it determines the magnitudes of disconfirmation of the expected performance. The performance itself and the impact of the performance will significantly and positively on customer satisfaction (Amstrong \& Seng, 2000).

Onthecorporatelevelorenterpriselevel,therearetwomainfactorsthatcanaffectcustomer satisfaction. The first one is the quality of the services and the second one is thequalityofthegoodsorinthiscasetheproductsoftheproject.Projectmanagement is part of the service being delivered to the customer. How the project team performstheprojectwillaffectdirectlyandindirectlythequalityofthedeliverables of the project. This shows us how important the performance of the project team is in fulfillingcustomer satisfaction(Nagel\&Cilliers,1990).Asdiscussedpreviously, the quality of the product is the degree of achievement of the project's products or services to meet the customer requirements andexpectations.

\section{Methodology}

The research will use descriptive method, which will be researching, analyzing and presenting the gathered data so that it can provide a clear picture of the research objectives, which are the relationship of project performance and customer satisfaction, what is(are) the most dominant factor(s) and the business implications.

The data of this research was taken from a questionnaire, which customers of the projects took. The questionnaire was given in order to identify how the project team's performance in managing the project affected their satisfaction. There were 38 questions withascaleof1to5;scale1represented 'reallyunsatisfied'andscale5represented 'very satisfied'. The respondents, which were the customers of the project, 
answered the questionnaire by choosing the answer that defined their experiences themost.

Figure 1 shows the flow of the research method that was carried out by the researcher (Sekaran \& Bougie, 2016)

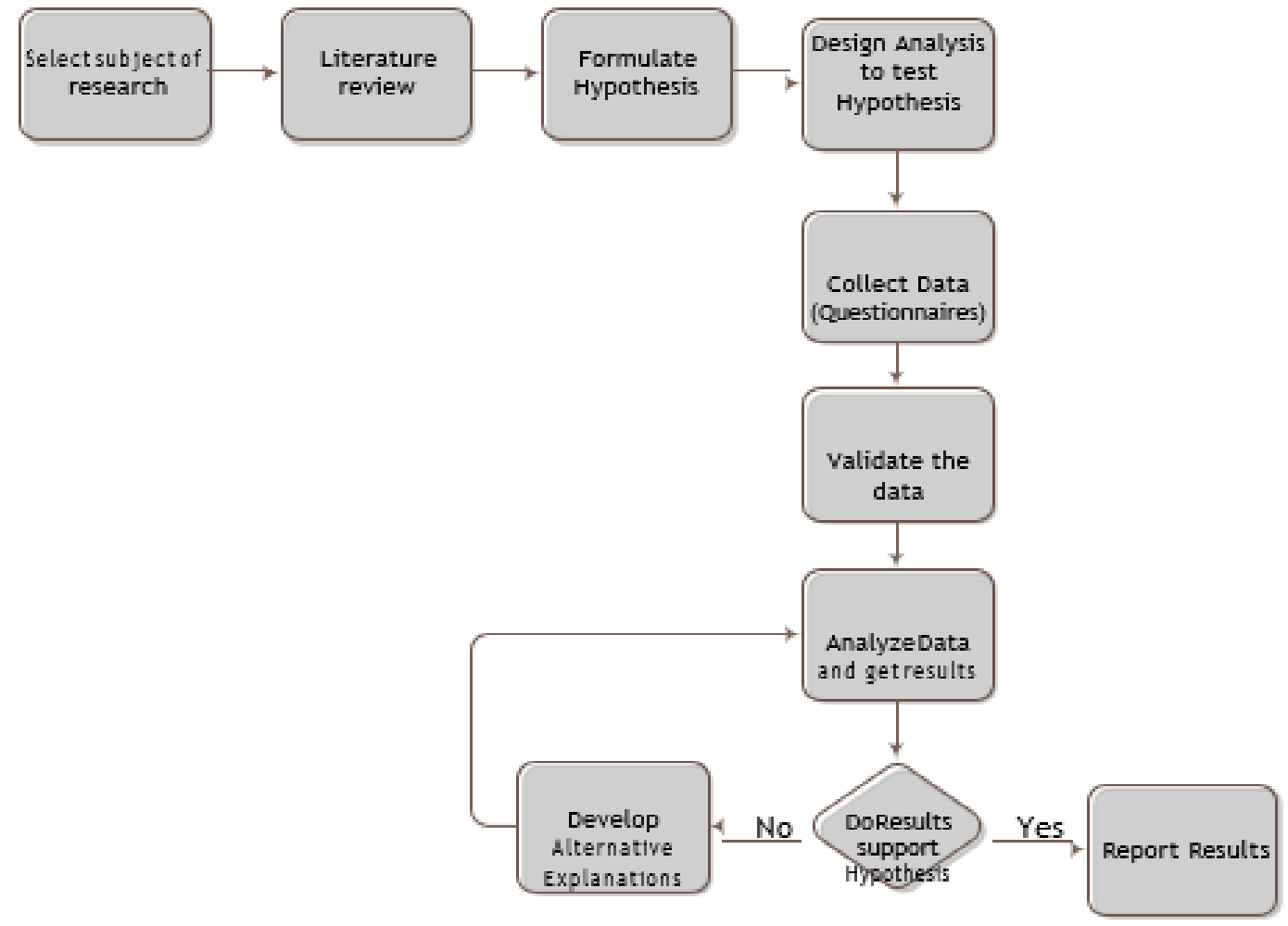

Figure 1. Research Method

In this research the independent variables for project performance consists of eight variables namely:

1. Scope ManagementPerformance

2. Schedule ManagementPerformance

3. Cost ManagementPerformance

4. Resources ManagementPerformance

5. Risk ManagementPerformance

6. Quality ManagementPerformance

7. Communication ManagementPerformance

8. Stakeholder ManagementPerformance

And the dependent variable is Customer Satisfaction

This research is conducted from July 2017 to March2018. Data was collected in Bandung, during the Symposium and Exhibition of Project Management Institute Indonesia Chapter was conducted, and in Jakarta where most of the companies in Indonesia have theirheadquarters.

\section{Research Model}

The model of this research is depicted as follow. 


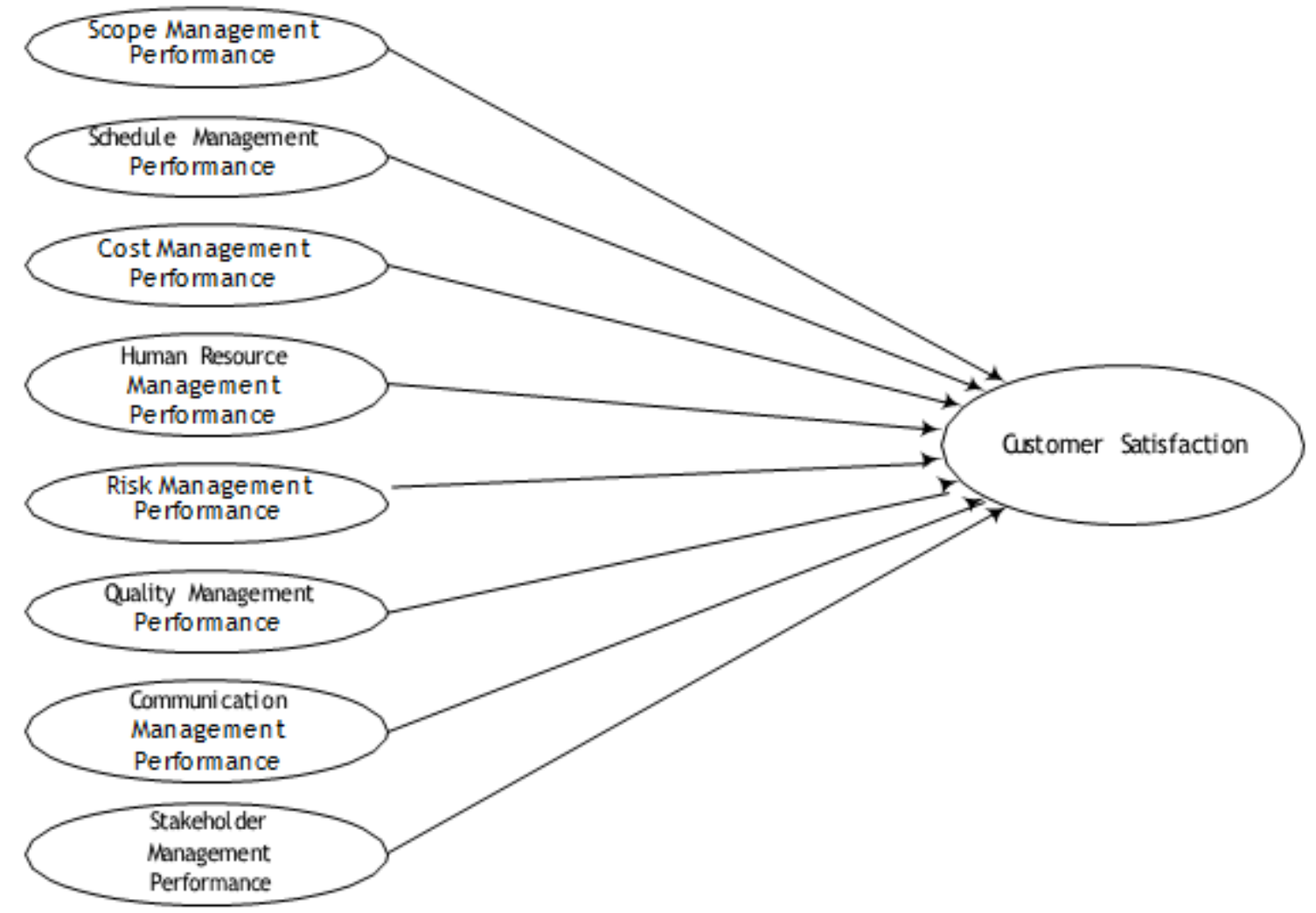

Figure 2. Research Model

Based on the research model, this research developed eight hypotheses:

Hypothesis $1(\mathrm{H} 1)$ : There is a positive correlation between project scope management performance and customer satisfaction

Hypothesis $2(\mathrm{H} 2)$ : There is a positive correlation between project schedule management performance with customer satisfaction

Hypothesis $3(\mathrm{H} 3)$ : There is a positive correlation between project cost management performance with customer satisfaction

Hypothesis 4 (H4): There is a positive correlation between project human resources management performance with customer satisfaction

Hypothesis 5 (H5): There is a positive correlation between project risk management performance with customer satisfaction

Hypothesis 6 (H6): There is a positive correlation between project quality management performance with customer satisfaction

Hypothesis 7 (H7): There is a positive correlation between project communication management performance with customer satisfaction

Hypothesis 8 (H8): There is a positive correlation between project stakeholder management performance with customer satisfaction

\section{Population and Sampling}

Sample were taken from population of managers or decision makers in the field of operation and production of companies in Jakarta and Bandung. Sampling technique used convenience sampling with quota sampling approach. The researcher managed to get valid 112 response from 112 respondents. Data were collected from distributed questionnaire using online line and email as media.

\section{Data Analysis Technique}

Data analysis was conducted with data validity and reliability tests, continued with descriptive statistics analysis, multiple regression analysis stepwise regression analysis and completed with interviews. 


\section{Findings and Discussion}

\section{Respondents Profile}

There are $77.7 \%$ male and $22.3 \%$ female respondents. About $33 \%$ of the respondents are project managers, $23.2 \%$ of the respondents are functional managers $21.4 \%$ of them are directors, VPs or general managers. Respondents came from various industries, but IT (26.8\%), telecommunication provider (25.9\%) and oil, gas and mining $(8 \%)$ are the top three industries. Among them $45.5 \%$ of the respondents work on multinational companies, while $54.5 \%$ of them work for local companies. Most of the respondents have project management experiences more than 7 years $(64.3 \%), 6-7$ years $(14.3 \%)$ and $4-5$ years $(15.2 \%)$. Validity and

\section{Reliability Test}

Table 1 to table 9 show the results of validity test that were conducted for the data for each variable, for the items that were not valid were not included in these tables

Table 1 Validity Test Result for Scope

\begin{tabular}{|c|c|c|c|c|}
\hline Variable & Indicator & KMO & Sig & Factor Loading \\
\hline \multirow{6}{*}{ Scope } & $\mathrm{SCO} 02$ & \multirow{6}{*}{.767} & \multirow{6}{*}{.000} & .697 \\
\hline & $\mathrm{SCO} 03$ & & & .720 \\
\hline & $\mathrm{SCO} 04$ & & & .640 \\
\hline & $\mathrm{SCO} 05$ & & & .728 \\
\hline & SCO06 & & & .688 \\
\hline & SCO07 & & & .618 \\
\hline
\end{tabular}

Table 2 Validity Test Result for Schedule

\begin{tabular}{|c|c|c|c|c|}
\hline Variable & Indicator & $\mathrm{KMO}$ & Sig & Factor Loading \\
\hline \multirow{5}{*}{ Schedule } & $\mathrm{SCH} 01$ & \multirow{5}{*}{0.812} & \multirow{5}{*}{.000} & .726 \\
\hline & $\mathrm{SCH} 02$ & & & .784 \\
\hline & $\mathrm{SCH} 03$ & & & .831 \\
\hline & SCH04 & & & .770 \\
\hline & $\mathrm{SCH} 05$ & & & .658 \\
\hline
\end{tabular}

Table 3 Validity Test Result for Cost

\begin{tabular}{|c|c|c|c|c|}
\hline Variable & Indicator & $\mathrm{KMO}$ & Sig & Factor Loading \\
\hline \multirow{3}{*}{ Cost } & COS01 & \multirow{3}{*}{.593} & \multirow{3}{*}{.000} & 843 \\
\hline & $\mathrm{COS} 02$ & & & 864 \\
\hline & COS05 & & & 620 \\
\hline
\end{tabular}

\begin{tabular}{|c|c|c|c|c|}
\hline Variable & Indicator & KMO & Sig & Factor Loading \\
\hline \multirow{9}{*}{ Risk } & RIS01 & \multirow{9}{*}{.877} & \multirow{9}{*}{.000} & .645 \\
\hline & RIS02 & & & .744 \\
\hline & RIS03 & & & .830 \\
\hline & RIS04 & & & .769 \\
\hline & RIS05 & & & .699 \\
\hline & RIS06 & & & .652 \\
\hline & RIS07 & & & .796 \\
\hline & RIS08 & & & .768 \\
\hline & RIS09 & & & .782 \\
\hline
\end{tabular}

Table 6 Validity Test Result for Quality

\begin{tabular}{|c|c|c|c|c|}
\hline Variable & Indicator & KMO & Sig & Factor Loading \\
\hline \multirow{4}{*}{ Quality } & QUL01 & \multirow{4}{*}{.743} & \multirow{3}{*}{.000} & .841 \\
\cline { 2 - 2 } \cline { 5 - 5 } & QUL02 & & .849 \\
\cline { 2 - 3 } & QUL03 & & .843 \\
\cline { 2 - 3 } & QUL04 & & & .794 \\
\hline
\end{tabular}

Table 7 Validity Test Result for Communication

\begin{tabular}{|c|c|c|c|c|}
\hline Variable & Indicator & KMO & Sig & Factor Loading \\
\hline \multirow{4}{*}{ Communication } & COM01 & & & .667 \\
\cline { 2 - 2 } & COM02 & \multirow{4}{*}{.737} & \multirow{2}{*}{.000} & .608 \\
\cline { 2 - 2 } & COM03 & .757 \\
\cline { 2 - 3 } & COM04 & & .646 \\
\cline { 2 - 3 } & COM05 & & .766 \\
\hline
\end{tabular}


Table 7 Validity Test Result for Communication

\begin{tabular}{|c|c|c|c|c|}
\hline Variable & Indicator & KMO & Sig & Factor Loading \\
\hline \multirow{5}{*}{ Communication } & COM01 & \multirow{5}{*}{.737} & \multirow{5}{*}{.000} & .667 \\
\hline & COM02 & & & .608 \\
\hline & COM03 & & & .757 \\
\hline & COM04 & & & .646 \\
\hline & COM05 & & & .766 \\
\hline
\end{tabular}

Table 8 Validity Test Result for Stakeholder

\begin{tabular}{|c|c|c|c|c|}
\hline Variable & Indicator & KMO & Sig & Factor Loading \\
\hline \multirow{4}{*}{ Stakeholder } & STA01 & \multirow{4}{*}{.738} & \multirow{4}{*}{.000} & .678 \\
\hline & STA02 & & & .945 \\
\hline & STA03 & & & .902 \\
\hline & STA04 & & & .800 \\
\hline
\end{tabular}

Table 9 Validity Test Result for Customer Satisfaction

\begin{tabular}{|c|c|c|c|c|}
\hline Variable & Indicator & KMO & Sig & Factor Loading \\
\hline \multirow{9}{*}{$\begin{array}{l}\text { Customer } \\
\text { Satisfaction }\end{array}$} & CUS01 & \multirow{9}{*}{.878} & \multirow{9}{*}{.000} & .787 \\
\hline & CUS02 & & & .774 \\
\hline & CUS03 & & & .831 \\
\hline & CUS04 & & & .815 \\
\hline & CUS05 & & & .858 \\
\hline & CUS06 & & & .836 \\
\hline & CUS07 & & & .787 \\
\hline & CUS08 & & & .760 \\
\hline & CUS09 & & & .647 \\
\hline
\end{tabular}

Table 10 shows the result of reliability testing for the data that had already been tested and proved reliable .

Comparing the respondent's feedback based on their company profile, it was found that there were different perspectives related to independent variables, but on the dependent variables, both local and multinational company respondent's answers were equal as can be seen below:

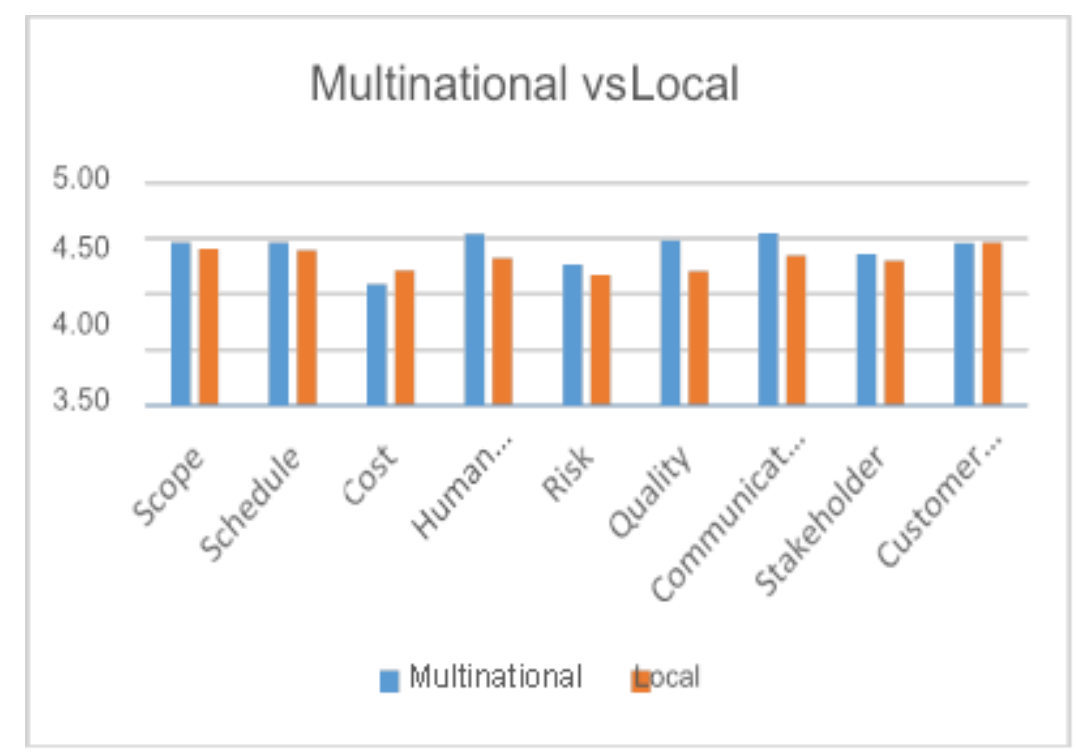

Figure 3. Respondents' Responses Based on Company's Profile

Figure above show, from scale 1 to 5 in the questionnaire, the average answers from the multinational company were higher on project scope, schedule, human resources, risk, quality, communication and stakeholder management performance. Only on project cost management performance, the average scored from local company's respondents were higher compare to the multinational company's respondents. For customer satisfaction. The highest gap was in the project quality management performance (4.48 to 4.21$)$ that indicated that multinational companies value quality more than local companies. 


\section{Model Summary}

Based on the analysis that was done using SPSS, table 6.11 shows the result of model summary

Table 11. Model Summary

\begin{tabular}{||l|c|r|r|r|}
\hline \multicolumn{5}{|c|}{ Model Summary } \\
\hline Model & $\mathrm{R}$ & R Square & $\begin{array}{c}\text { Std. } \\
\text { Adjusted } \\
\text { R Square }\end{array}$ & $\begin{array}{c}\text { Error of } \\
\text { the } \\
\text { Estimate }\end{array}$ \\
\hline 1 & $.740^{\mathrm{a}}$ & .548 & .513 & .33060 \\
\hline
\end{tabular}

a. Predictors: (Constant), Stakeholder, Schedule, Cost, Scope, Communication, Quality, Risk, Human_Resource

\section{F-Test}

Table 12 shows the F-Test result. It can be concluded that the research regression model was valid with a pvalue or significance of 0.000 where the independent variables; scope management performance, schedule management performance, cost management performance, quality management performance, risk management performance, human resources management performance, communication management performance, and stakeholder management performance have a significant impact on customer satisfaction.

Table 12. ANOVA Table

\begin{tabular}{|c|c|c|c|c|c|c|}
\hline \multicolumn{7}{|c|}{ ANOVA $^{a}$} \\
\hline \multicolumn{2}{|c|}{ Model } & $\begin{array}{l}\text { Sum of } \\
\text { Squares }\end{array}$ & $d f$ & $\begin{array}{l}\text { Mean } \\
\text { Square }\end{array}$ & $\mathrm{F}$ & Sig. \\
\hline \multirow[t]{3}{*}{1} & Regression & 13.661 & 8 & 1.708 & 15.624 & $.000^{b}$ \\
\hline & Residual & 11.257 & 103 & .109 & & \\
\hline & Total & 24.918 & 111 & & & \\
\hline
\end{tabular}

a. Dependent Variable: Customer_Satisfaction

b. Predictors: (Constant), Stakeholder, Schedule, Cost, Scope, Communication, Quality, Risk, Human_Resource

\section{Hypothesis Testing}

The hypothesis testing is resented in bellow tables.

Table 13. Coefficients of Regression Standardized Residual

\begin{tabular}{|c|c|c|c|c|c|c|}
\hline \multicolumn{7}{|c|}{ Coefficients $^{a}$} \\
\hline \multirow{2}{*}{\multicolumn{2}{|c|}{ Model }} & \multicolumn{2}{|c|}{$\begin{array}{l}\text { Unstandardized } \\
\text { Coefficients }\end{array}$} & \multirow{2}{*}{$\begin{array}{c}\begin{array}{c}\text { Standard } \\
\text { ized } \\
\text { Coefficie } \\
\text { nts }\end{array} \\
\text { Beta }\end{array}$} & \multirow[b]{2}{*}{$t$} & \multirow[b]{2}{*}{ Sig. } \\
\hline & & B & $\begin{array}{l}\text { Std. } \\
\text { Error }\end{array}$ & & & \\
\hline \multirow[t]{9}{*}{1} & (Constant) & .869 & .377 & & 2.304 & .023 \\
\hline & Scope & -.017 & .080 & -.018 & -.214 & .831 \\
\hline & Schedule & .214 & .078 & .234 & 2.763 & .007 \\
\hline & Cost & .121 & .055 & .178 & 2.216 & .029 \\
\hline & Human_Resource & .278 & .113 & .284 & 2.459 & .016 \\
\hline & Risk & .169 & .100 & .194 & 1.685 & .095 \\
\hline & Quality & -.024 & .078 & -.028 & -.307 & .759 \\
\hline & Communication & .030 & .090 & .031 & .330 & .742 \\
\hline & Stakeholder & .057 & .058 & .075 & .972 & .334 \\
\hline
\end{tabular}


Table 14 t-Test Result

\begin{tabular}{|l|c|c|l|}
\hline \multicolumn{1}{|c|}{ Variable } & $\begin{array}{c}\text { Regression } \\
\text { Coefficients }\end{array}$ & Sig. & \multicolumn{1}{|c|}{ Conclusion } \\
\hline Scope & -.017 & .831 & Not Significant \\
\hline Schedule & .214 & .007 & Significant \\
\hline Cost & .121 & .029 & Significant \\
\hline Human Resource & .278 & .016 & Significant \\
\hline Risk & .169 & .095 & Not Significant \\
\hline Quality & -.024 & .759 & Not Significant \\
\hline Communication & .030 & .742 & Not Significant \\
\hline Stakeholder & .057 & .334 & Not Significant \\
\hline
\end{tabular}

Table 14 shows only 3 independent variables that actually impacted significantly on the dependent variable (customer satisfaction) for the p-value was lower than 0.05 . The independent variables were schedule management performance, human resource management performance and cost management performance. The researcher discussed this result with 20 respondents: CXO, VP, GM, or senior managers from their companies, and they agreed on the result, stating that the presence of experts on the project, the capability of the project team to meet the deadline and lower costs would significantly affect their customer satisfaction. Below is the formula showing the multiple regression model for this research

$\mathrm{Y}=0.869-0.017 \mathrm{X} 1+0.214 \mathrm{X} 2+0.121 \mathrm{X} 3+0.278 \mathrm{X} 4+0.169 \mathrm{X} 5-0.024 \mathrm{X} 6+0.030 \mathrm{X} 7+0.057 \mathrm{X} 80.030$ $\mathrm{X} 7+0.057 \mathrm{X} 8$

Where

$\mathrm{Y}=$ Customer Satisfaction

X1 = Project Scope Management Performance

X2 = Project Schedule Management Performance

X3 = Project Cost Management Performance

X4 = Project Resources Management Performance

X5 $=$ Project Risk Management Performance

X6 = Project Quality Management Performance

X7 = Project Communication Management Performance

X8 $=$ Project Stakeholder Management Performance

\section{Stepwise Analysis}

Table 15 and 16 show the result of using Stepwise Regression Analysis that focused only on the most significant variables that impacted customer satisfaction as the dependent variable.

Table 15. Stepwise Analysis Model Summary

\begin{tabular}{|l|l|r|r|r|}
\hline \multicolumn{5}{|c|}{ Model Summary } \\
\hline Model & R & R Square & $\begin{array}{c}\text { Adjusted R } \\
\text { Square }\end{array}$ & $\begin{array}{c}\text { Std. Error of } \\
\text { the Estimate }\end{array}$ \\
\hline 1 & $.650^{\mathrm{a}}$ & .422 & .417 & .36183 \\
2 & $.700^{\mathrm{b}}$ & .491 & .481 & .34126 \\
3 & $.723^{\circ}$ & .523 & .509 & .33191 \\
4 & $.737^{\text {d }}$ & .543 & .526 & .32623 \\
\hline \multicolumn{5}{|l|}{ a. Predictors: (Constant), Human_Resource } \\
b. Predictors: (Constant), Human_Resource, Cost \\
c. Predictors: (Constant), Human_Resource, Cost, Schedule \\
d. Predictors: (Constant), Human_Resource, Cost, Schedule, Risk \\
\hline
\end{tabular}

Table 16. Stepwise Regression Analysis 


\begin{tabular}{|c|c|c|c|c|c|c|}
\hline \multicolumn{7}{|c|}{ Coefficients $^{a}$} \\
\hline \multirow{2}{*}{\multicolumn{2}{|c|}{ Model }} & \multicolumn{2}{|c|}{ Unstandardized Coefficients } & \multirow{2}{*}{$\begin{array}{c}\begin{array}{c}\text { Standardized } \\
\text { Coefficients }\end{array} \\
\text { Beta }\end{array}$} & \multirow[b]{2}{*}{$\mathrm{t}$} & \multirow[b]{2}{*}{ Sig. } \\
\hline & & $\mathrm{B}$ & Std. Error & & & \\
\hline \multirow[t]{2}{*}{1} & (Constant) & 1.645 & .316 & & 5.211 & .000 \\
\hline & Human_Resource & .636 & .071 & .650 & 8.963 & .000 \\
\hline \multirow[t]{3}{*}{2} & (Constant) & 1.317 & .310 & & 4.251 & .000 \\
\hline & Human_Resource & .529 & .072 & .541 & 7.298 & .000 \\
\hline & Cost & .193 & .050 & .284 & 3.829 & .000 \\
\hline \multirow[t]{4}{*}{3} & (Constant) & 1.028 & .320 & & 3.213 & .002 \\
\hline & Human_Resource & .413 & .083 & .422 & 5.002 & .000 \\
\hline & Cost & .165 & .050 & .243 & 3.309 & .001 \\
\hline & Schedule & .207 & .077 & .226 & 2.689 & .008 \\
\hline \multirow[t]{5}{*}{4} & (Constant) & .965 & .316 & & 3.056 & .003 \\
\hline & Human_Resource & .276 & .102 & .282 & 2.695 & .008 \\
\hline & Cost & .125 & .052 & .184 & 2.382 & .019 \\
\hline & Schedule & .213 & .076 & .233 & 2.816 & .006 \\
\hline & Risk & .192 & .088 & .220 & 2.190 & .031 \\
\hline
\end{tabular}

Stepwise regression analysis shows the sequence of the top variables that impacted customer satisfaction the most. From the tables above, they showed that human resources management performance was the top variable that impacted customer satisfaction the most, followed by cost management performance, schedule management performance and risk management performance.

Based on the results above, below are the formula showing the stepwise regression model for this research:

$\mathrm{Y}=0.965+0.276 \mathrm{X} 1+0.125 \mathrm{X} 2+0.213 \mathrm{X} 3+0.192 \mathrm{X} 4$

Where:

$\mathrm{Y}=$ Customer Satisfaction

$\mathrm{X} 1$ = Project human resource Management Performance

$\mathrm{X} 2=$ Project Cost Management Performance

X3 = Project Schedule Management Performance

X4 = Project Resources Management Performance

This analysis actually describes the behavior of the Indonesian project's customer, and from the analysis it can be concluded that making sure the performing organization has experts as part of the project team (or making sure the project team has the right skill to deliver the project) was something that would significantly impact customer satisfaction. The second one was cost management performance of the project that tells us most of the customers preferred not to add any additional costs even though the project would have issues with the quality of the deliverables. The third most significant factor that impacted customer satisfaction is the schedule management performance. This tells us that meeting the project timeline would significantly impact on customer satisfaction, that in some cases sacrifices the quality of the deliverables too like in achieving the ability to maintain the costs of the project that was previously discussed.

\section{Conclusion}

This research concluded that for Indonesian project management practitioners that most of them were the users/customers of the projects that were being performed; the project schedule, cost, human resource and risk management performance were the factors that actually impacted significantly and positively on customer satisfaction. While the project schedule, communication and stakeholder management performance did not impact significantly on customer satisfaction.

\section{Managerial Implication}

Based on the results of the research, there are several things that can be highlighted in creating a business strategy. 
1. To win a project in Indonesia, making a guarantee that the project will be on time, offering the lowest cost and the presence of experts in delivering the project will be very crucial and deal breakers in the procurement process.

2. Proper project feasibility study and customer requirements accommodation will increase the probability of the project to deliver the intended benefits to the company or organization.

3. Projects should be created to support the program, portfolio, vision and mission of an organization. Leadership is a crucial component to make sure that all the required stakeholders will positively support any project that will be executed.

4. Project quality management that can help one organization in achieving the most from project deliverables is still not considered as important, causing many projects not to add significant value or benefits to the performing organization.

5. Crashing methodology in fast tracking a project is common; that will add cost and produce more risk in the project.

\section{Further Research}

There are several suggestions from the researcher for any future research related to project management performance impact on customer satisfaction.

1. This research focus was only for Indonesian project management practitioners; it is suggested in the future to have research that has a wider audience such as finance, operations, or sales which are not directly involved during the project execution.

2. Related to human resource management, this research focused only for the capability of the project manager to makes sure that the project team will consist of required personnel that match the requirements of the project; it is suggested to conduct research focusing on the impact of project management leadership on customer satisfaction.

3. To conduct research that investigates the factors during the project initiation that can impact project performance and customer satisfaction.

4. To conduct research that investigates the impact of project maturity level on customer satisfaction.

5. To conduct research with respondents from public sectors, since most of the respondents on this research are from private sectors.

\section{References}

Books

Sekaran, U. \& Bougie, R. (2016). Research methods for business (7th Ed.). Sussex, UK: John Wiley \& Sons Journals

Armstrong, R. W., \& Seng, T. B. (2000). Corporate-customer satisfaction in the banking industry of Singapore. International Journal of Bank Marketing, Vol. 18 Iss: 3 pp. 97 - 111

Blanas G., Koukoumialos S. \& Kylindri S. (2012), Reverse logistics strategic antinomies: the case of the automotive sector, International Journal of Business Science \& Applied Management, Vol 7, Issue 3,

Nagel, P. J., \& Cilliers, W. (1990). Customer Satisfaction: A Comprehensive Approach. International Journal of Physical Distribution \& Logistics Management, Vol. 20 Iss 6 pp. 2 - 46

Project Management Institute. (2013a). A Guide to the Project Management Body of Knowledge (PMBOK Guide), 5th edition. Pennsylvania, United States 